\begin{tabular}{|l|c|c|c|r|}
\hline $\begin{array}{l}\text { Cuadernos de Investigación Geográfica } \\
\text { Geographical Research Letters }\end{array}$ & 2017 & $\mathbf{N}^{\circ} 43(2)$ & pp. 553-570 & $\begin{array}{r}\text { ISSN 0211-6820 } \\
\text { eISSN 1697-9540 }\end{array}$ \\
\hline
\end{tabular}

DOI: http://doi.org/10.18172/cig.3238

(C) Universidad de La Rioja

\title{
THE DEGLACIATION OF THE MOUNTAINS OF MEXICO AND CENTRAL AMERICA
}

\author{
L. VÁZQUEZ-SELEM ${ }^{1 *}$, M.S. LACHNIET ${ }^{2}$ \\ 'Instituto de Geografía, Universidad Nacional Autónoma de México, \\ Ciudad Universitaria, 04510 Ciudad de México, México. \\ ${ }^{2}$ Department of Geoscience, University of Nevada, Las Vegas, \\ 4505 Maryland Parkway, Las Vegas, NV 89154, USA.
}

\begin{abstract}
The last deglaciation is an interval of marked changes in the climate system. The records of glaciation of tropical mountains offer unique opportunities to assess the timing of changes and the sensitivity of tropical climates to global and regional atmospheric phenomena. Here we summarize the existing knowledge on the glacial history of the highest mountains of the Trans Mexican Volcanic Belt $\left(19.5^{\circ} \mathrm{N}\right)$ and Central America (Cuchumatanes in Guatemala, $15.5^{\circ} \mathrm{N}$; Cerro Chirripo in Costa Rica, $\left.9.5^{\circ} \mathrm{N}\right)$, focusing on the transition from the last local glacial maximum (LLGM) to the early Holocene, with some emphasis on records supported by cosmogenic nuclide dating. The LLGM in the mountains of Mexico (20-14 ka) and Central America ( 21-18 ka) overlaps with the final part of the global Last Glacial Maximum (26.5-19 ka). A depression of the equilibrium line altitude (ELA) of glaciers of 1500-1000 $\mathrm{m}$ with respect to modern values is indicative of $9-6^{\circ} \mathrm{C}$ cooling. Deglaciation in Costa Rica started by $18 \mathrm{ka}$, while in Mexico glaciers remained at or near their maximum position until $\sim 15 \mathrm{ka}$, probably due to the influence of Heinrich event 1. Glacier retreat commenced at 15-14 ka in central Mexico and accelerated from 14 to $13 \mathrm{ka}$, in coincidence

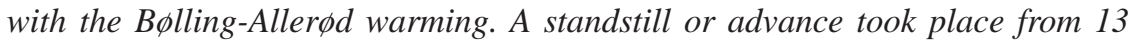
to $10.5 \mathrm{ka}$ in Mexico. In Costa Rica, undated moraines formed between 18 and $10 \mathrm{ka}$. Full deglaciation across the region is recorded at $\sim 10 \mathrm{ka}$, except on the mountains of central Mexico $>4200 \mathrm{~m}$, and can be explained by a rise of the ELA of 300 to $450 \mathrm{~m}$ (warming of $\sim 2-3^{\circ} \mathrm{C}$ ) relative to the LLGM. In general, the deglacial records of central Mexico and Central America seem to be controlled by temperature. However, the temporal pattern of deglaciation of Costa Rica is similar to that of the northern tropical Andes, while the one from central Mexico is in agreement with the chronology of the western USA.
\end{abstract}

\section{La deglaciación de las montañas de México y América Central}

RESUMEN. La deglaciación después del Último Máximo Glacial es un intervalo de fuertes cambios en el clima planetario. Los registros de glaciación de las 
montañas tropicales representan una oportunidad excepcional para evaluar la temporalidad de los cambios y la sensibilidad de los climas tropicales ante los fenómenos atmosféricos globales y regionales. En este artículo presentamos el estado del conocimiento sobre la cronología glacial de las altas montañas del centro de México $\left(19.5^{\circ} \mathrm{N}\right.$ ) y América Central (Altos Cuchumatanes en Guatemala, $15.5^{\circ} \mathrm{N}$; Cerro Chrirripó en Costa Rica, $\left.9.5^{\circ} \mathrm{N}\right)$, con énfasis en la transición entre el último máximo glacial local (UMGL) y el Holoceno temprano y con especial atención en cronologías basadas en dataciones cosmogénicas de geoformas. El UMGL en México (20-14 ka) y América Central ( 21-18 ka) coincide con el final del Último Máximo Glacial planetario (26.5-19 ka). La altitud de la línea de equilibrio (ALE) de los glaciares se encontraba deprimida 1500-1000 m con respecto a la actual e indica temperaturas $9-6^{\circ} \mathrm{C}$ por debajo de las actuales. La deglaciación en Costa Rica se inició en $18 \mathrm{ka}$, mientras que en México los glaciares permanecieron en su posición máxima o cerca de ella hasta 15 ka, probablemente en respuesta al evento Heinrich-1. El retroceso de los glaciares en el centro de México comenzó en 15-14 ka y se aceleró entre 14 y 13 ka, en coincidencia con la fase cálida del Bølling-Allerød. Una pausa en el retroceso o un avance ocurrió entre 13 y 10.5 ka en México. En Costa Rica, morrenas no fechadas se formaron entre 18 y $10 \mathrm{ka}$. Hacia $\sim 10 \mathrm{ka}$ se registra una deglaciación total en toda la región estudiada, con excepción de las montañas de $>4200 \mathrm{~m}$, y puede atribuirse a un ascenso de la ALE de 300 a $450 \mathrm{~m}$ (calentamiento de $\sim 2-3^{\circ} \mathrm{C}$ ) con respecto a valores del UMGL. En general las cronologías de la deglaciación del centro de México y América Central parecen estar controladas por cambios en la temperatura. Sin embargo, el patrón temporal de deglaciación de Costa Rica es similar al de los Andes tropicales del norte, mientras que el de México se asemeja más al de las montañas del occidente de los EUA.

Key words: tropical glaciation, ELA, late glacial, Pleistocene-Holocene transition, Bølling-Allerød, Mexico, Guatemala, Costa Rica.

Palabras clave: glaciación tropical, ALE, glacial tardío, transición PleistocenoHoloceno, Bølling-Allerød, México, Guatemala, Costa Rica.

Received: 7 February 2017

Accepted: 30 March 2017

* Corresponding author: Lorenzo Vázquez-Selem, Instituto de Geografía, Universidad Nacional Autónoma de México, Ciudad Universitaria, 04510 Ciudad de México, México. E-mail address: lselem@igg.unam.mx

\section{Introduction}

Glaciers are primary indicators of climate change, both for modern and past times. Research on past glaciation has mainly focused on the phases of moraine construction, when glaciers reach equilibrium with climate and deposit sediments for some time at a certain position. In the last 25 years, surface exposure dating of moraines based on the 
in situ accumulation of cosmogenic nuclides has greatly improved our knowledge on past glaciation (Granger et al., 2013), thus allowing new regional and global synthesis of knowledge (e.g. Ehlers et al., 2011; Clark et al., 2009). The last deglaciation was punctuated by abrupt climatic shifts, including the global abrupt warming that initiated the Bølling-Allerød interstadial (Rosen et al., 2014) and the cooling/warming associated to the onset/end of the Younger Dryas stadial (Broecker et al., 2010). As glaciers are one of the most responsive systems to climate change (Lowell, 2000), the study of the temporal and spatial patterns of deglaciation can yield valuable information on the timing and propagation of such climatic events.

The mountain systems along the American continent offer the possibility to examine glacial chronologies from north to south and across the tropics. The aim of this paper is to review the existing knowledge on the timing of deglaciation in the high mountains of central Mexico and Central America $\left(19.5^{\circ} \mathrm{N}\right.$ to $9.5^{\circ} \mathrm{N}$, Fig. 1) during the last glacial-interglacial transition, from the MIS-2 last local glacial maximum (LLGM) to the early Holocene. This includes assessing the timing of maximum advance with respect to the global Last Glacial Maximum (LGM), the onset and pace of deglaciation, as well as the possible influence of well-known events such as

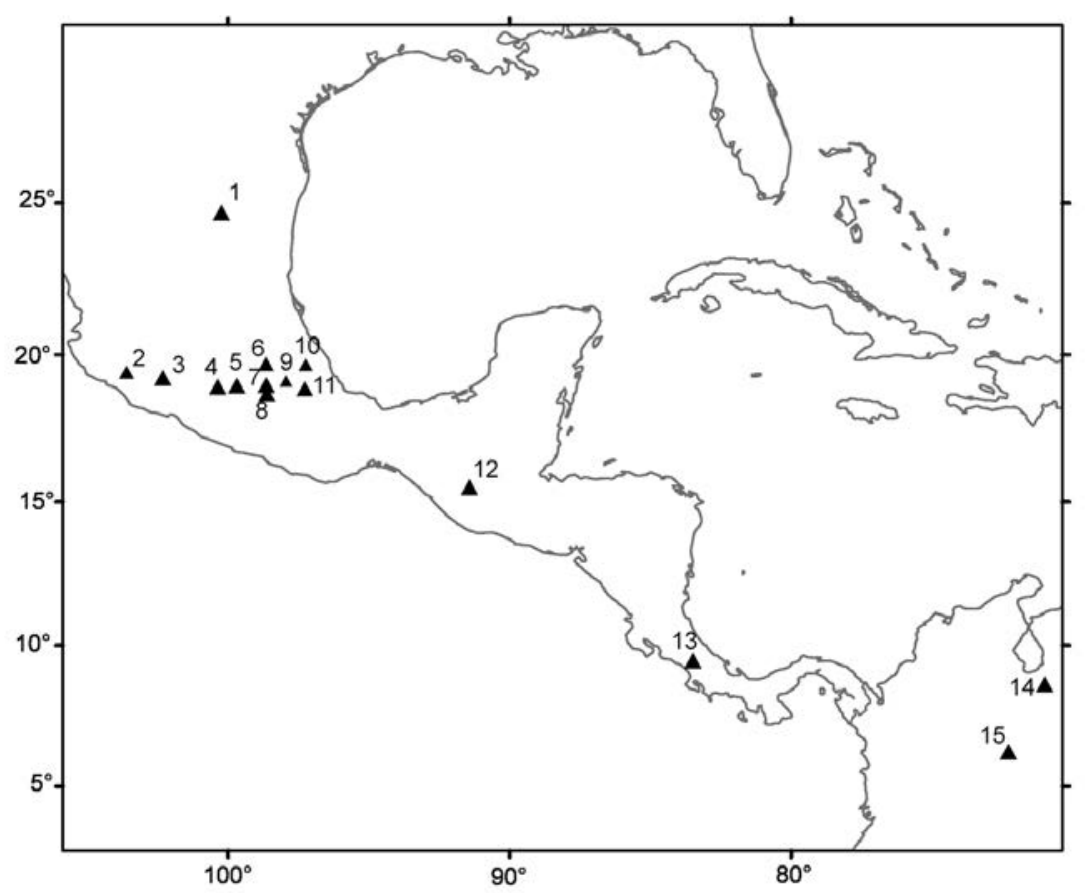

Figure 1. Location of glaciated mountains of Mexico and Central America and other mountain ranges mentioned in the text. 1. Cerro Potosí. 2. Nevado de Colima. 3. Tancítaro. 4. Nevado de Toluca. 5. Ajusco. 6. Tláloc-Telapón. 7. Iztaccíhuatl. 8. Popocatépetl.9. Malinche. 10. Cofre de Perote. 11. Pico de Orizaba. 12. Altos Cuchumatanes. 13. Cerro Chrirripó. 14. Mérida Andes (Venezuela). 15. Sierra Nevada del Cocuy (Colombia). 
Heinrich event 1, the Bølling-Allerød warming, and the Younger Dryas cooling. Our review is based mainly on published studies, but also includes some unpublished data from ongoing research.

The glacial chronology of central Mexico was largely developed by White (1962, 1986) and by Heine $(1975,1988,1994)$, with subsequent contributions by VazquezSelem (1997; 2000) and Vázquez-Selem and Heine (2011). In Central America, evidence of Pleistocene glaciation is known only for Sierra Altos Cuchumatanes in Guatemala (Anderson, 1969; Hastenrath, 1974; Roy and Lachniet, 2010) and for the Cordillera de Talamanca in Costa Rica (Weyl, 1956; Hastenrath, 1973; Orvis and Horn, 2000; Lachniet and Selzer, 2002). Lachniet and Vázquez-Selem (2005) studied the late Pleistocene equilibrium line altitude (ELA) of glaciers for the circum-Caribbean region, and determined a LGM ELA depression of 1500-1000 m in Mexico and Central America, compared to the modern regional ELA ( 4900 m).

\section{Central México}

Ten stratovolcanoes of the Trans-Mexican Volcanic Belt (TMVB) show evidence of late Pleistocene glaciation (Vázquez Selem and Heine, 2011) (Fig. 1). Three of them peak above $5000 \mathrm{~m}$ (Pico de Orizaba, Popocatépetl and Iztaccíhuatl) and supported small glaciers in the second half of the 20th century. In the last few decades, rapid recession has considerably reduced the area and volume of glaciers, while recent volcanic activity wiped out those of Popocatépetl (Delgado et al., 2015). In some mountains, volcanic activity of the last 20,000 yr largely obliterated the glacial record. Other high elevation volcanoes are too young to have a glacial record.

Apart from the high volcanoes of the TMBV, there is evidence of glaciation in Cerro Potosí (3715 m), located in the Sierra Madre Oriental, northeastern Mexico (VázquezSelem and Heine, 2011). The reconstructed glacier is compatible with the equilibrium line altitude (ELA) of the late Pleistocene glaciers of central Mexico and the SW USA, but dating is pending.

The following review is based on published data, but also includes unpublished data for several peaks. It focuses on the mountains with the most complete records, in particular on those where cosmogenic surface exposure dating has been used. Of special relevance for the analysis of deglaciation are exposure ages of glacially abraded bedrock left behind during glacier recession.

\subsection{Iztaccíhuatl}

Iztaccíhuatl stratovolcano $(5286 \mathrm{~m})$ has been essentially inactive since ca. $80 \mathrm{ka}$ ( $\mathrm{ka}=$ thousands of years before present) (Nixon 1989), whereas the late Pleistocene and Holocene glacial record is well preserved (White, 1962, 1986; Heine, 1975, 1988, 1994). It is indeed the longest and best dated record of glaciation for central Mexico, supported by tephrostratigraphy, ${ }^{14} \mathrm{C}$ dating and over 100 cosmogenic ${ }^{36} \mathrm{Cl}$ surface exposure ages (Vázquez-Selem, 2000; Vázquez-Selem and Heine, 2011). ${ }^{36} \mathrm{Cl}$ ages from Iztaccíhuatl (and from other mountains discussed here) were calculated using recently published ${ }^{36} \mathrm{Cl}$ 
production rates (Marrero et al., 2016) and the calculator by Schimmelpfennig et al. (2009). These calculations yield ages 2 to 5\% younger than those reported by VázquezSelem and Heine (2011). A full re-analysis of exposure ages and the glacial chronology of Iztaccíhuatl will be published elsewhere.

The oldest glacial deposits on Iztaccíhuatl yield ${ }^{36} \mathrm{Cl}$ exposure ages within MIS-6. No younger deposits prior to MIS-2 have been identified so far.

The Last Local Glacial Maximum (LLGM) is represented by Hueyatlaco-1 moraines (White, 1962). These moraines indicate a mean glacier terminus of $3390 \pm 160 \mathrm{~m}$ and a mean ELA (based on THAR=0.4) of $3940 \pm 130 \mathrm{~m}$, i.e. $\sim 1000 \mathrm{~m}$ lower than the modern (1960 CE) ELA of 4970 m (Fig. 2). Nine moraine boulders yield exposure ages ranging from $19.0 \pm 1.8 \mathrm{ka}$ to $11.7 \pm 1.9 \mathrm{ka}$ (mean $14.9 \pm 1.9 \mathrm{ka}$ ). In addition, a prominent pumice layer from the neighbor Popocatépetl volcano dated at 17,000 cal yr BP (Sosa-Ceballos et al., 2012) mantled Hueyatlaco-1 moraines, thus providing a minimum limiting age for their formation. Subsequently, in most valleys glaciers retreated a short distance (mean of $110 \mathrm{~m}$ in horizontal distance, $\sim 100 \mathrm{~m}$ of ELA rise) and built a second set of similar moraines (Hueyatlaco-2), which are not mantled by the $\sim 17$ ka pumice. Exposure ages from 18 boulders range from 19.6 to $11.6 \mathrm{ka}$ (10 of them between 17 and $14 \mathrm{ka}$ ) with a mean of $14.7 \mathrm{ka}$. This suggests that the $40-50 \mathrm{~m}$ thick moraines formed over a period of ca. three millennia, during which the ELA remained at $4040 \mathrm{~m} \pm 130 \mathrm{~m}$ and the glacier termini at $3500 \pm 190 \mathrm{~m}$.

Subsequently glaciers thinned down and formed recessional moraines in some valleys. Single boulders from such moraines yield exposure ages of 14.0, 13.9 and $13.3 \pm 1.5 \mathrm{ka}$, thus suggesting recession in progress around $14 \mathrm{ka}$ and short thereafter. ${ }^{36} \mathrm{Cl}$ samples of glacially polished bedrock located above recessional moraines provide further details on the timing of deglaciation. Ten samples of glacial polish were collected at sites located in between Hueyatlaco- 2 and the younger Milpulco- 1 moraines. Four samples of polished side-walls from 3 different valleys yield a mean exposure age of $16.9 \pm 1.7 \mathrm{ka}$, while six samples of polished bedrock from near-bottom positions of 5 valleys at elevations ranging from 3575 to 3960 m yield a mean age of $14.1 \pm 1.7 \mathrm{ka}$ (age range: 16.0 - $12.7 \mathrm{ka}$ ). Samples from near-bottom sites probably yield a better estimate of the timing of major recession, as glaciers erode more actively near the center than on the sides of valleys, thus minimizing the effect of ${ }^{36} \mathrm{Cl}$ inherited from pre-glacial times. In summary, ${ }^{36} \mathrm{Cl}$ exposure ages suggest recession in progress around $14 \mathrm{ka}$ (probably since $\sim 16$ ka in marginal parts of some valleys), with short periods of moraine formation between $\sim 14$ and $>13 \mathrm{ka}$ at elevations between 3850 and $3700 \mathrm{~m}$, then hillslopes gradually becoming ice-free up to ca. $3900 \mathrm{~m}$ around $13 \mathrm{ka}$. From $\sim 14.5 \mathrm{ka}$ (when the main Hueyatlaco-2 moraines were still actively forming) to $\sim 13 \mathrm{ka}$, glacier termini rose ca. $300 \mathrm{~m}$ in elevation (from 3500 to $>3800 \mathrm{~m}$ ), while the mean ELA moved upwards at least $200 \mathrm{~m}$ from its maximum position at $4040 \pm 140 \mathrm{~m}$ (Fig. 2).

Milpulco-1 moraines represent either a standstill in the deglaciation of Iztaccíhuatl or a re-advance during the Pleistocene-Holocene transition. They are low latero-frontal ridges (in general $<6 \mathrm{~m}$ high), present on most valleys of the mountain. Overall their maximum positions indicate a mean terminus at $3810 \pm 80 \mathrm{~m}$ and a mean ELA of $4240 \pm 60$, thus $\sim 300 \mathrm{~m}$ 

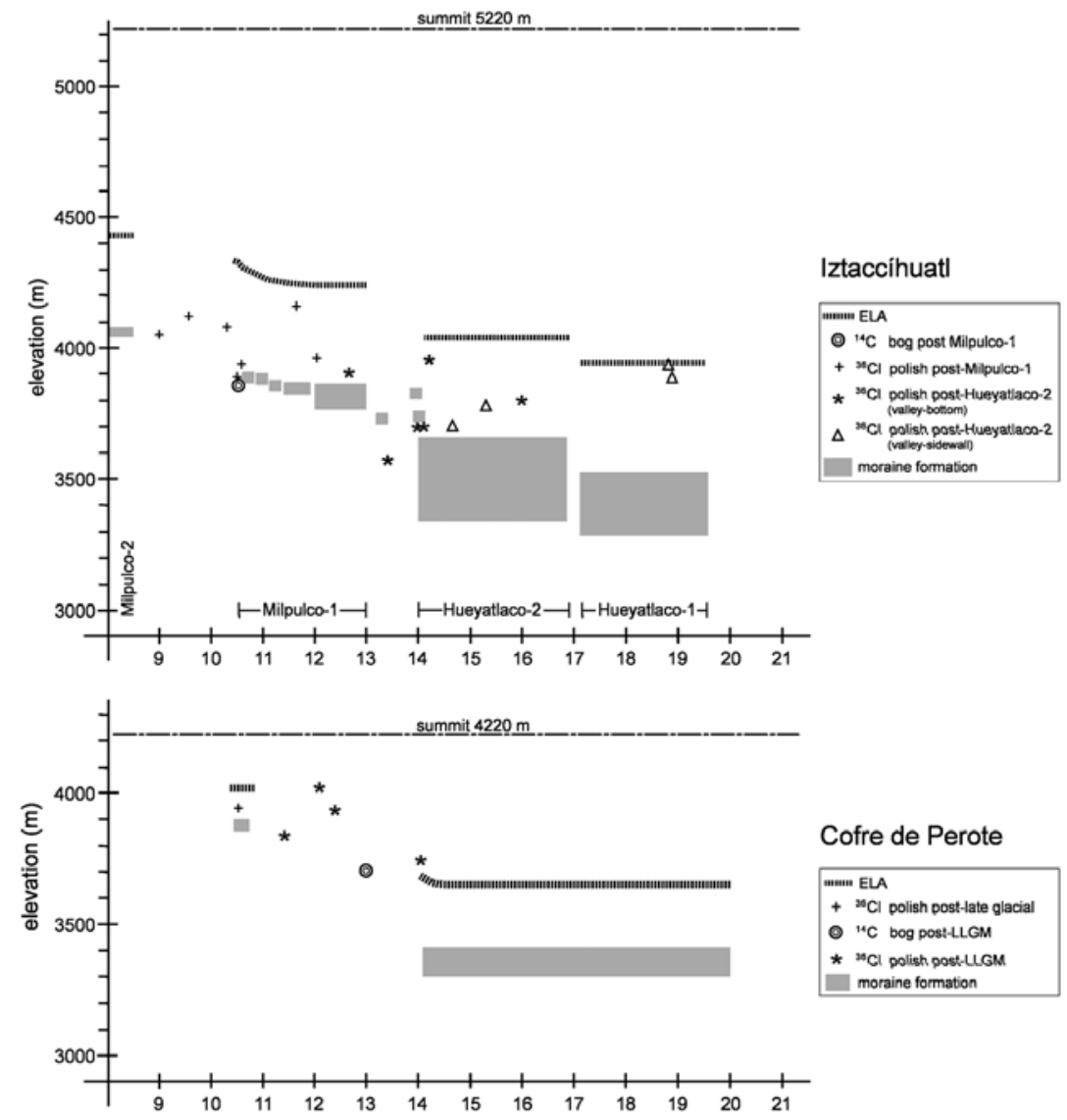

\section{Cofre de Perote}
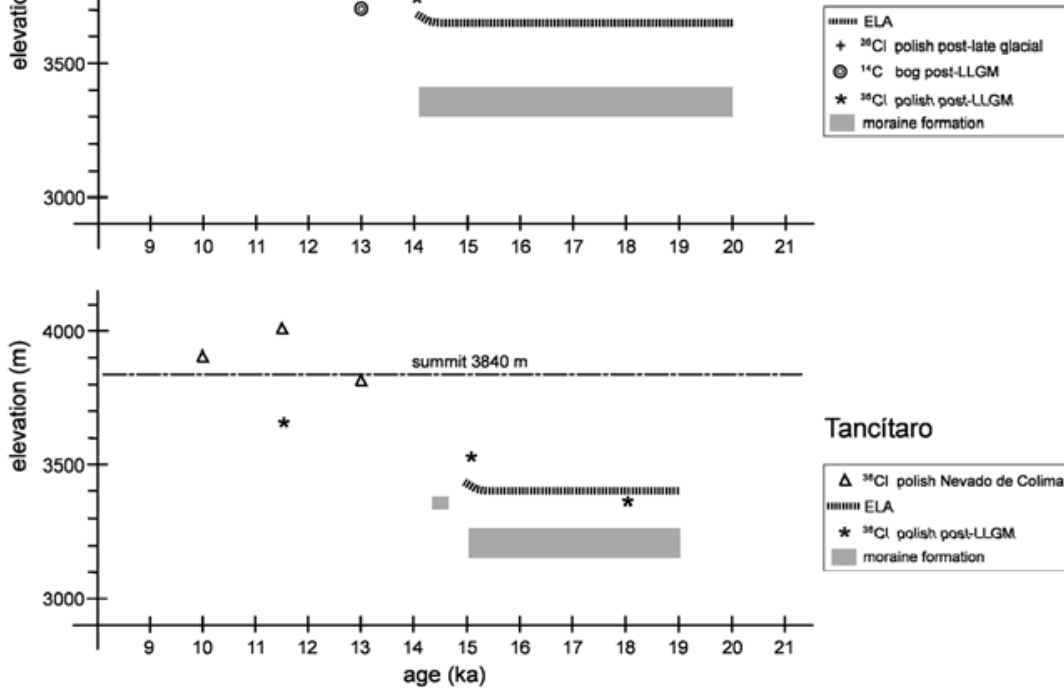

\section{Tancítaro}

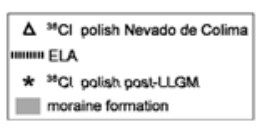

Figure 2. Generalized glacial chronology of three mountains of central Mexico (Iztaccíhuatl, Cofre de Perote and Tancitaro) showing the timing of LLGM and deglaciation. Grey rectangles represent the general timing and elevation range of LLGM moraines as indicated by existing ${ }^{36} \mathrm{Cl}$ exposure ages, ${ }^{14} \mathrm{C}$ ages and tephrostratigraphy. Stars, crosses and open triangles indicate specific ${ }^{36} \mathrm{Cl}$ exposure ages of glacially abraded bedrock left behind during deglaciation. Circles are ${ }^{14} \mathrm{C}$ ages from bog sediments representing maximum limiting timing of deglaciation. Notice that open triangles correspond to ${ }^{36} \mathrm{Cl}$ ages of glacial polish from Nevado de Colima placed on the graph of Tancítaro. 
above the LLGM ELA and $\sim 750 \mathrm{~m}$ below the modern ELA. Closely spaced recessional moraines at short distance from the maximum position indicate a very slow pace of recession in several valleys. Thirty eight ${ }^{36} \mathrm{Cl}$ exposure ages from nine different valleys suggest the following chronology: formation of moraines of the maximum advance (3770-3925 m) from 13 to $12 \mathrm{ka}$; formation of latest recessional moraines (3860-4180 m) from 11.5 to $10.5 \mathrm{ka}$; final glacier recession and exposure of polished bedrock (3900-4200 m) from 10.5 to $9 \mathrm{ka}$, but probably earlier ( $12 \mathrm{ka}$ ) on marginal valleys with headwalls below $4600 \mathrm{~m}$. In addition, radiocarbon dating of sediments dammed by a recessional moraine at $3880 \mathrm{~m}$ indicates recession shortly before 10.2-10.9 cal yr B.P. (Lozano-García and Vázquez-Selem, 2005). After the peak of the advance (13-12 ka) the ELA remained slightly above $4240 \mathrm{~m}$ for over one millennium, but by $10.5-9 \mathrm{ka}$ it had risen at least $100 \mathrm{~m}$, leaving all areas of the mountain below $4000 \mathrm{~m}$ ice-free (Fig. 2).

Two prominent Holocene advances are well recorded on Iztaccíhuatl. Milpulco-2 moraines are low bouldery ridges indicative of a widespread, short duration event with glacier termini at $\sim 4050 \mathrm{~m}$ and ELA at $\sim 4420 \mathrm{~m}$ (Fig. 2). ${ }^{36} \mathrm{Cl}$ exposure ages range from 8.5-7.5 ka (maximum advance) to $6.5 \mathrm{ka}$ (late recessional) on moraine boulders, and $\sim 7 \mathrm{ka}$ on glacial polish at 4300-4400 m. Ayoloco moraines are massive deposits formed during the Little Ice Age at elevations around $4500 \mathrm{~m}$.

\subsection{Cofre de Perote}

Cofre de Perote $(4230 \mathrm{~m})$, an inactive stratovolcano located on the eastern end of the TMVB, $80 \mathrm{~km}$ from the Gulf of Mexico (Fig. 1), shows clear evidence of Pleistocene glaciation (Vázquez-Selem and Heine, 2011). Deglaciation was probably a factor leading to the collapse of its eastern flank 13-11 ka (Carrasco-Núñez et al., 2010). Ten ${ }^{36} \mathrm{Cl}$ exposure ages from three latero-frontal moraines reaching 3300-3400 m on the northern flank suggest a maximum glacier advance between $\sim 20$ and $\sim 14 \mathrm{ka}$. The mean ELA was around $3650 \mathrm{~m}$ (1250 $\mathrm{m}$ lower than the modern ELA). The lack of recessional moraines suggests continuous recession along ca. $3 \mathrm{~km}$ of horizontal distance from the main moraines to near the summit area. Four samples of glacially polished bedrock suggest deglaciation of the northern valleys between $14 \mathrm{ka}(3740 \mathrm{~m})$ and $11.5 \mathrm{ka}(3830 \mathrm{~m})$; and full deglaciation of a south-facing valley from $12.5 \mathrm{ka}(3930 \mathrm{~m})$ to $12 \mathrm{ka}(4020 \mathrm{~m})$. In addition, radiocarbon dating from a bog located at $3715 \mathrm{~m}$ within a northern valley indicates deglaciation by 13 cal kyr BP (Fig. 2).

Bouldery moraine ridges on the cirque floors of two valleys at 3860-3840 m reveal the presence of small cirque glaciers. Samples from two moraine boulders around $3870 \mathrm{~m}$ and from a glacially abraded outcrop at $3940 \mathrm{~m}$ yield ${ }^{36} \mathrm{Cl}$ exposure ages of $\sim 10.5 \mathrm{ka}$.

To summarize, the available evidence indicates that the LLGM in Cofre de Perote is associated with an ELA around $3650 \mathrm{~m}$ from $\sim 20$ to $\sim 14 \mathrm{ka}$, with no discernable interruption. Recession was in progress on the north side between $14 \mathrm{ka}$ and $11.5 \mathrm{ka}$ and complete on south facing valleys by $12 \mathrm{ka}$. The mountain was mostly ice-free by $11 \mathrm{ka}$, except on two cirque floors below the summit headwalls, where small glaciers remained until $\sim 10.5 \mathrm{ka}$. From the LLGM position at $\sim 14 \mathrm{ka}$ to full deglaciation at $10.5 \mathrm{ka}$, the 
ELA rose nearly $400 \mathrm{~m}$. No evidence of Holocene glaciation has been identified, as the mountain is substantially lower than the ELAs of subsequent glacial advances recorded in central Mexico (4420 m for the early 8.5-7.5 ka advance, and $4720 \mathrm{~m}$ for the Little Ice Age advance; Vázquez Selem and Heine, 2011).

\subsection{Tancítaro}

Tancítaro (3842) is a stratovolcano located in west central Mexico, inactive since $\sim 240 \mathrm{ka}$ (Ownby et al., 2007). Notwithstanding its relatively low elevation, it shows distinctive glacial morphology, although somewhat subdued by tephra from the numerous monogenetic cones around it. LLGM glaciers reached elevations as low as 3300 to $3100 \mathrm{~m}$ and indicate a mean ELA around $3400 \mathrm{~m}$ (Lachniet and Vázquez Selem, 2005). ${ }^{36} \mathrm{Cl}$ exposure ages ( 6 on moraines boulders, 3 on glacial polish) indicate that LLGM glaciers built moraines from 19 to $15 \mathrm{ka}$ (Vázquez-Selem and Heine, 2011). Exposure ages on glacial polish suggests that glaciers became thinner by $18 \mathrm{ka}$, but recession probably started by $15 \mathrm{ka}$. Small recessional moraines formed around $14.5 \mathrm{ka}$ at $3300-3400 \mathrm{~m}$ at least in three valleys. By $11.5 \mathrm{ka}$ the headwalls at $3700 \mathrm{~m}$ were ice-free (Fig. 2). No evidence of a younger glacier advance has been identified.

\subsection{Nevado de Colima}

Nevado de Colima $(4180 \mathrm{~m})$ is located on the western end of the TMVB, $85 \mathrm{~km}$ from the Pacific Ocean. It was last active in the late Pleistocene (Macías, 2005), but shows clear signs of glaciation reaching elevations of at least 3500-3600 m (Lorenzo, 1961). Its flanks are covered by thick mantles of pyroclastic deposits from its active neighbor Volcán de Colima, which limits the use of cosmogenic exposure dating, in particular on gently sloping moraines. Nevertheless, on steep slopes around the main peak there are numerous outcrops with glacial striations and polish related to the timing of final deglaciation. Four ${ }^{36} \mathrm{Cl}$ ages on such polish indicate deglaciation of the southern flank progressing from $3800 \mathrm{~m}$ at $\sim 13 \mathrm{ka}$ to $4000 \mathrm{~m}$ at $\sim 11.5 \mathrm{ka}$; and deglaciation of the main cirque on the north flank at $3900 \mathrm{~m}$ by $10 \mathrm{ka}$ (Fig. 2).

\subsection{Malinche, Nevado de Toluca, Ajusco}

Heine $(1975,1988,1994)$ produced a detailed glacial chronology of Malinche volcano (4461 m) based on tephrostratigraphy and radiocarbon dating, which has been correlated to that of Iztaccíhuatl (see Vázquez-Selem and Heine, 2011). However, explosive volcanic activity on Malinche has been frequent throughout the late Pleistocene and Holocene, with episodes at 21.5, 20.9, 15.9, 12-9, 7.5 and $3.1 \mathrm{ka}$, including a sector collapse, ash and pumice fallouts and voluminous pyroclastic flow deposits on all flanks (Heine, 1975; Castro-Govea and Siebe, 2007). As a result, volcanism most likely affected glaciers during MIS-2 and largely overrode glacial features, thus making it difficult to determine the timing of deglaciation as related to climate.

The same applies to Nevado de Toluca $(4690 \mathrm{~m})$, where four major episodes of explosive volcanism between 26 and $12 \mathrm{ka}$, including voluminous pumice falls, dome 
collapses and pyroclastic flows (Macías, 2005), certainly interacted with glaciers and obliterated parts of the glacial record recognized by Heine $(1976,1988)$. In particular, the episode of dome collapse and related pyroclastic flow deposits of 17.4-16.2 ka; the plinian eruption of 15-14.5 ka; and the plinian eruption of 12.6-12 ka (calibrated radiocarbon ages) conceivably had a strong influence on glaciers and deglaciation of the volcano. Nevertheless, glaciers formed again during the Pleistocene-Holocene transition and in the Holocene, often evolving into rock glaciers (Heine, 1976), mirroring the Milpulco-1 and Milpulco-2 advances of Iztaccíhuatl in both timing and extent (Vázquez-Selem and Heine, 2011). ${ }^{36} \mathrm{Cl}$ dating of glacial polish on the plug dome inside the crater at $4300 \mathrm{~m}$ indicates deglaciation around $9 \mathrm{ka}$ (Arce et al., 2003).

White (1986; White and Valastro, 1984) investigated the glacial sequence of Ajusco $(3937 \mathrm{~m})$, a relatively low, inactive volcano located in the central portion of the TMVB only $40 \mathrm{~km}$ west of Iztaccíhuatl. A few radiocarbon limiting ages suggest that the Albergue moraines formed sometime between 20 and $12 \mathrm{ka}$, but there is no information on the timing of deglaciation.

\subsection{Active volcanoes: Pico de Orizaba, Popocatépetl, Colima, Tacaná}

The glacial record of the two highest peaks of Mexico, Pico de Orizaba (5640 m) and Popocatépetl $(5452 \mathrm{~m})$, is very sketchy because of recurrent volcanic activity throughout the late Pleistocene and Holocene (Macías, 2005). Mapping of Pico de Orizaba by Heine (1988) shows glacial features likely analogous to the series described for Iztaccíhuatl, especially on the north and northwest flanks, but this requires further study. In Popocatépetl most evidence of glaciation dates to the late Holocene (Heine, 1983; White, 1986; Espinasa-Pereña and Martín-Del Pozzo, 2006).

Likewise, no glacial features have been reported for two other major active stratovolcanoes of the TMVB, Volcán de Colima (3860 m) and Tacaná (4060 m), as their terminal cones formed almost entirely throughout the Holocene (Macías, 2005).

\section{Costa Rica and Guatemala}

Glacial landforms and deposits in the high mountains (>3400 m) of Costa Rica $\left(9.5^{\circ} \mathrm{N}\right)$ and Guatemala $\left(15.5^{\circ} \mathrm{N}\right)$ are well known (Fig. 1). Many previous studies delineated the approximate extent of paleoglaciers and equilibrium line altitudes in Costa Rica (Barquero and Ellenberg, 1986; Bergoeing, 1978; Hastenrath, 1973, 2009; Lachniet and Seltzer, 2002; Orvis and Horn, 2000; Shimizu, 1992; Weyl, 1956). Recent reviews detail the history of exploration and scientific progress in understanding glacial history and deposits in the Costa Rican páramos (Kappelle and Horn, 2016), and in glacial lakes around the $3819 \mathrm{~m}$ high Cerro Chirripó (Horn and Haberyan, 2016). Minimum ages of deglaciation in Costa Rica have been estimated from basal dates in glacial lakes (Horn and Haberyan, 2016). The precise timing of glacial expansions remains a topic of research, but first indications suggest a history of glacial expansions similar to those of the Mexican volcanoes. Unpublished data on ${ }^{10} \mathrm{Be}$ cosmogenic nuclide exposure ages from Morrenas Valley around Cerro Chirripó (Cunningham et al., 2015) suggest 
moraine formation between ca. 17 and $18.5 \mathrm{ka}$. Moraine formation in Morrenas Valley from ${ }^{36} \mathrm{Cl}$ ages indicate maximum expansion around the LGM, 21-18 ka, with subsequent recessional phases until deglaciation ca. $10 \mathrm{ka}$ (Li et al., 2015; Potter, 2015). Further precision on glacial cosmogenic geochronology awaits publications in which details on production rates, scaling, and age distributions are presented in more detail.

The most extensive LGM glacial expansion was associated with equilibrium line altitudes between 3355 (Orvis and Horn, 2000) and $3480 \mathrm{~m}$ (Lachniet and VazquezSelem, 2005), indicating ELA depression of $1500 \mathrm{~m}$ compared to the modern level of ca. $4900 \pm 200 \mathrm{~m}$. These data, and the late age of full deglaciation of the Chirripó regions (ca. $10 \mathrm{ka}$ ), are strong indicators of extreme glacial temperature depression in the inner tropics.

Less information is available on the chronology of glacial expansions and retreat in Guatemala. First efforts conclusively demonstrated the glacial geomorphology of the high Altos de Cuchumatanes (3837 m), a broad low-relief limestone plateau mostly above 3500 m altitude (Anderson, 1969, 1969b; Anderson et al., 1973; Hastenrath, 1973, 1974; Lachniet and Roy, 2011; Roy and Lachniet, 2010). Mapping of glacial limits indicate an ice cap of $\sim 42 \mathrm{~km}^{2}$ in extent, called the Mayan Ice Cap by Roy and Lachniet (2010). ELAs were estimated to be $3670 \mathrm{~m}$ for the plateau ice cap. Nearby peaks around Montaña San Juan $(3784 \mathrm{~m})$ contained northeast-facing valley glaciers reaching as low as $3000 \mathrm{~m}$ altitude, that delineated paleoglaciers with ELAs around $3470 \mathrm{~m}$. The glacial moraines consist of limestone debris and boulders. A preliminary attempt to date boulders perched on these moraines is in progress using ${ }^{36} \mathrm{Cl}$ cosmogenic nuclides, but challenges in estimating the rate of chemical erosion in this environment may lead to age uncertainties that are significantly larger than those arising from analytical uncertainties. Additionally, several now-dry moraine dammed lakes are present in the glaciated area, several of which are targets for coring in on-going research to attempt basal radiocarbon dating to provide minimum ages of deglaciation. Unfortunately, very little organic material was found in and around glacial deposits in the Cuchumatanes region, making the geochronology of moraines there uncertain. However, given the close proximity to the Mexican glacial sequence, it appears reasonable to assign a similar age to the glacial deposits in Guatemala. ELA depression during maximum glacial expansion was between 1100 and 1400 m (Lachniet and Roy, 2011; Roy and Lachniet, 2010). Temperature depressions at maximum glacial extent assuming modern lapse rates was between 5.9 and $7.6 \pm 1.2^{\circ} \mathrm{C}$ (Roy and Lachniet, 2010).

\section{Discussion}

\subsection{Timing of LLGM and deglaciation}

Recent research on the glacial chronology of central Mexico and central America shows that the LLGM is coeval to the final part of the global LGM (26.5 to $19 \mathrm{ka}$ according to Clark et al., 2009): 21-18 ka in Cerro Chirripó, Costa Rica (Li et al., 2015); ca. 19-18 ka in Iztaccíhuatl, 19-15 ka in Tancítaro, and 20- 14 ka in Cofre de Perote, central Mexico (Vazquez-Selem and Heine, 2011) (Table 1). The onset or deglaciation at $18 \mathrm{ka}$ 
in Chirripó is somewhat mirrored by the retreat from Hueyatlaco-1 to Hueyatlaco-2 moraines on Iztaccíhuatl (ELA rise of ca. $100 \mathrm{~m}$ ) short before $17 \mathrm{ka}$. However, available evidence for the central Mexican mountains overall shows that glaciers stayed at or near their maximum positions until 15-14 ka. The formation of recessional moraines at close distance from the LLGM position is recorded between $\sim 14.5$ and $>13 \mathrm{ka}$ on Iztaccíhuatl and Tancítaro.

Table 1. Estimated shifts of the ELA of glaciers (and related temperature changes) from the LLGM to full deglaciation on the mountains of central Mexico and Central America. The calculations assume steady deglaciation and hence do not consider standstills recorded by late glacial moraines on Iztaccíhuatl, Cofre de Perote and Chirripó. The calculations also assume that ELA depends only on temperature. ELA-derived temperature changes are based on a lapse rate of $0.65^{\circ} \mathrm{C} / 100 \mathrm{~m}$.

\begin{tabular}{l|c|c|c|c|c}
\hline $\begin{array}{l}\text { Mountain } \\
\text { (altitude) }\end{array}$ & $\begin{array}{c}\text { Age of } \\
\text { end of } \\
\text { LLGM }\end{array}$ & $\begin{array}{c}\text { Age of full } \\
\text { deglaciation }\end{array}$ & $\begin{array}{c}\text { ELA shift from } \\
\text { LLGM to } \\
\text { full deglaciation } \\
\text { (ELA rise) }\end{array}$ & $\begin{array}{c}\text { Temperature } \\
\text { rise from } \\
\text { LLGM to full } \\
\text { deglaciation }\end{array}$ & $\begin{array}{c}\text { Rate of ELA } \\
\text { ascent from } \\
\text { LLGM to } \\
\text { full deglaciation }\end{array}$ \\
\hline $\begin{array}{l}\text { Iztaccíhuatl } \\
(5220 \mathrm{~m})\end{array}$ & $\sim 14 \mathrm{ka}$ & $\sim 10 \mathrm{ka} *$ & $\begin{array}{c}4040 \mathrm{~m}->4400 \mathrm{~m} \\
(>350 \mathrm{~m})\end{array}$ & $2-2.5^{\circ} \mathrm{C}$ & $90 \mathrm{~m} / \mathrm{ka}$ \\
\hline $\begin{array}{l}\text { Cofre de } \\
\text { Perote } \\
(4220 \mathrm{~m})\end{array}$ & $14 \mathrm{ka}$ & $\sim 10.5 \mathrm{ka}$ & $\begin{array}{c}3650 \mathrm{~m}->4000 \mathrm{~m} \\
(\sim 400 \mathrm{~m})\end{array}$ & $\sim 2.5^{\circ} \mathrm{C}$ & $115 \mathrm{~m} / \mathrm{ka}$ \\
\hline $\begin{array}{l}\text { Tancítaro } \\
(3840 \mathrm{~m})\end{array}$ & $\sim 15 \mathrm{ka}$ & $11.5 \mathrm{ka}$ & $\begin{array}{c}3400 \mathrm{~m}->3800 \mathrm{~m} \\
(\sim 400 \mathrm{~m})\end{array}$ & $\sim 2.5^{\circ} \mathrm{C}$ & $115 \mathrm{~m} / \mathrm{ka}$ \\
\hline $\begin{array}{l}\text { Chirripó } \\
(3819 \mathrm{~m})\end{array}$ & $18 \mathrm{ka}$ & $\sim 10 \mathrm{ka}$ & $\begin{array}{c}\sim 3500 \mathrm{~m}->3800 \mathrm{~m} \\
(\sim 300 \mathrm{~m})\end{array}$ & $\sim 2^{\circ} \mathrm{C}$ & $40 \mathrm{~m} / \mathrm{ka}$ \\
\hline
\end{tabular}

* Deglaciation of areas at $>3900-4100 \mathrm{~m}$

Exposure ages of post-LLGM glacial polish, a feature directly associated to recession, in general range from 15-11.5 ka (with probable thinning down of glaciers by $18 \mathrm{ka}$ ) on Tancítaro; 14.5-9 ka on Iztaccíhuatl (probably since $16 \mathrm{ka}$ on marginal areas of some valleys); and 14- 10.5 ka on Cofre de Perote (Fig. 2). However, a phase of glacier advance (or at least standstill) is recorded in the central Mexican mountains higher than $4200 \mathrm{~m}$ by the formation of closely spaced moraines at $13-12 \mathrm{ka}$ and lasting until ca. $10.5 \mathrm{ka}$. Likewise, in Cerro Chirripó (3819 m) moraines of two different phases formed after the LLGM and by $\sim 10$ ka deglaciation was complete (Potter et al., 2015; Li et al., 2015). Interestingly, glacial polish related to full deglaciation yields exposure ages of $\sim 10.5 \mathrm{ka}$ on Cofre de Perote $(4230 \mathrm{~m})$, ca. $10 \mathrm{ka}$ on Nevado de Colima $(4180 \mathrm{~m})$, and $\sim 11.5 \mathrm{ka}$ on Tancítaro (3842). On Iztaccíhuatl (5286 m) sites at 3900-4100 m became ice-free between $\sim 10.5$ and $9 \mathrm{ka}$. Thus, taking into consideration the uncertainties of cosmogenic exposure ages, full deglaciation (or deglaciation on Iztaccíhuatl below $4100 \mathrm{~m}$ ) occurred around $10 \mathrm{ka}$ in central Mexico and Costa Rica. 


\subsection{ELA shifts and deglaciation}

Table 1 summarizes the estimated changes of the ELA of glaciers (and associated temperature changes) in central Mexico and Costa Rica from the LLGM to full deglaciation. On Cerro Chirripó, between $18 \mathrm{ka}$ (LLGM) and $10 \mathrm{ka}$ (full deglaciation) the ELA rose ca. $300 \mathrm{~m}$ (equivalent to $\sim 2^{\circ} \mathrm{C}$ of warming). Because the highest peaks at Chirripó (and Cuchumatanes) are $<3900 \mathrm{~m}$, an ELA rise of only $\sim 300 \mathrm{~m}$, corresponding to a temperature increase of $\sim 2^{\circ} \mathrm{C}$, would be sufficient to provoke complete deglaciation. Likewise, in Cofre de Perote the ELA ascended $\sim 400 \mathrm{~m}$ (warming of $2.5^{\circ} \mathrm{C}$ ) between $14 \mathrm{ka}$ and $\sim 10.5 \mathrm{ka}$, which implies an average ELA shift of $115 \mathrm{~m} / \mathrm{ka}$. In Tancítaro the transition from LLGM to deglaciation implies an ELA ascent of $\sim 400 \mathrm{~m}\left(\sim 2.5^{\circ} \mathrm{C}\right)$ over 3500 years, i.e. $115 \mathrm{~m} / \mathrm{ka}$. In Iztaccíhuatl, an ELA rise of $\sim 350 \mathrm{~m}\left(2^{\circ} \mathrm{C}\right)$ is estimated for the period 14-10 ka, but most of the change $(200 \mathrm{~m})$ took place between $14 \mathrm{ka}$ and $13 \mathrm{ka} \mathrm{(} \mathrm{200} \mathrm{m/ka)} \mathrm{(see} \mathrm{Fig.} \mathrm{2).} \mathrm{The} \mathrm{former} \mathrm{calculations} \mathrm{assume} \mathrm{that:} \mathrm{(a)} \mathrm{ELA} \mathrm{rose}$ steadily, which was not the case from 13 to $11 \mathrm{ka}$, when moraines developed at least on the Mexican mountains; and (b) ELAs are controlled exclusively by temperature, which is not the case at least for the LLGM, when ELAs of the more continental (and hence colder) Iztaccíhuatl were 300-500 m higher than those of Cofre de Perote and Tancítaro, substantially lower mountains located near the oceans.

The ELAs for Altos Cuchumatanes (3670-3470 m) fall within the range of LLGM ELAs of Costa Rica and central Mexico, which supports a similar timing for the maximum expansion of glaciers in Guatemala, i.e. 20-18 ka (Roy and Lachniet, 2010). Considering the elevation of the Cuchumatanes plateau and mountains, the ELA rise of ca. $400 \mathrm{~m}$ estimated for central Mexico between 14 and $10 \mathrm{ka}$ (i.e., ca. $100 \mathrm{~m} / \mathrm{ka}$ ), potentially implies full deglaciation of Altos Cuchumatanes well before $10 \mathrm{ka}$, probably by $12 \mathrm{ka}$.

\subsection{Comparison with other glacial and paleoclimate records}

The timing of LLGM and deglaciation described above for central Mexico and Central America is in general agreement with the chronologies of mountain areas both North and South. The sequence of central Mexico shows clear similarities with those of mountains of the western USA. There, most glaciers remained near their (Pinedale) maximum until ca. $16 \mathrm{ka}$, deglaciation started synchronously between ca. 16 and $15 \mathrm{ka}$, and full deglaciation took place between ca. 15 and ca. $13 \mathrm{ka}$, driven by the BøllingAllerød warming (Young et al., 2011). In the Sierra Nevada, California $\left(37^{\circ} \mathrm{N}\right)$, abrupt recession to the crest of the mountain from 15 to $14.5 \mathrm{ka}$ was followed by a brief minor advance at $13.4 \mathrm{ka}$ (Phillips, 2009), thus similar to central Mexico allowing for dating uncertainties.

In contrast, deglaciation apparently followed a different pattern in the northern tropical Andes. In the Mérida Andes of Venezuela $\left(8.5-9^{\circ} \mathrm{N}\right)$ glacier retreat took place between $\sim 21$ and $16.5 \mathrm{ka}$, with complete deglaciation by $16 \mathrm{ka}$, according to ${ }^{10} \mathrm{Be}$ dating of glacial landforms on the SE flank (Angel et al., 2016). A ${ }^{14} \mathrm{C}$-dated record of lake and bog sediments indicates deglaciation between 19.7 and $15.7 \mathrm{ka}$ also on the wetter SE 
side (and $14.2 \mathrm{ka}$ on the dry NW side), followed by subsequent minor advances at 14.9$13.8 \mathrm{ka}$ and 13.8-10.0 ka, then extensive deglaciation by $10 \mathrm{ka}$ (Stansell et al., 2005). Early deglaciation (22 to $19.5 \mathrm{ka}$ ) has also been postulated for the tropical southern Andes (Seltzer et al., 2002). The sequence described for Chrirripó, with deglaciation at $\sim 18 \mathrm{ka}$, two minor advances and complete deglaciation by $10 \mathrm{ka}$, is compatible with the chronology of the northern tropical Andes of Venezuela and Colombia. The timing of the post-LLGM minor advances is not known. However, it must be noted that in the Sierra Nevada del Cocuy, Colombia $\left(6.5^{\circ} \mathrm{N}\right)$, there is evidence of a glacial advance within the Antarctic Cold Reversal (14.5-12.9 ka), followed by a minor advance or stillstand during the late Younger Dryas, the latter in connection with abrupt regional warming (Jomelli et al., 2014).

In summary, the general timing of deglaciation of Chirripó is similar to that of the northern tropical Andes (in particular the onset of deglaciation well before $16 \mathrm{ka}$ ), while the chronology of central Mexico shares more features with the chronologies from the western USA (onset of deglaciation at 16-15 ka, marked deglaciation between 15 and $\sim 13 \mathrm{ka})$.

On a cautionary note, the chronologies based on cosmogenic nuclide dating may still vary substantially as the knowledge on scaling and production rates of specific nuclides progresses. The glacial chronologies of central Mexico presented here, for instance, are based on production rates of ${ }^{36} \mathrm{Cl}$ recently published by Marrero et al. (2016). However, if other production rates are used (e.g., spallation from $\mathrm{Ca}$ as in Schimmelpfennig et al., 2011; spallation from K as in Schimmelpfennig et al., 2014), ages get older by 1-3 ka for samples within the LGM-early Holocene range. In addition, typical uncertainties for ${ }^{36} \mathrm{Cl}$ exposure ages range between 1 and $2 \mathrm{ka}$. Therefore, any correlation must remain tentative at this point. Nevertheless, it is worth emphasizing the general coherence of the chronologies presented for central Mexico and Central America, with respect to each other and to their counterparts of western North America and northern South America, as stated above. Other possible relevant correlations for central Mexico are: the general coincidence of deglaciation with the Bølling-Allerød warm interstadial; the timing of Milpulco-1 moraines within the Younger Dryas chronozone; the age of Milpulco-2 moraines spanning the $8.2 \mathrm{ka}$ cold event (Alley and Ágústsdóttir, 2005).

Overall, glacial advances of central Mexico seem to be controlled by regionally cold conditions somewhat modulated by moisture (see Lachniet et al., 2013). The LLGM coincides with cold and wet conditions, the latter produced by a strong monsoon. Considering the regional evidence of drying around $17 \mathrm{ka}$, it is possible that glacier recession and ELA ascent of $\sim 100 \mathrm{~m}$ between $\sim 18 \mathrm{ka}$ (Hueyatlaco-1 moraines) and $\sim 17 \mathrm{ka}$ (Hueyatlaco-2) on Iztaccíhuatl (but not on lower mountains located near the oceans), resulted from lower precipitation, inasmuch as temperatures remained low in connection with Heinrich stadial 1 (Lachniet et al., 2013). From this perspective, it seems plausible that the low ELA represented by Hueyatlaco-2 moraines and the late deglaciation of the mountains of central Mexico resulted from low temperatures associated with Heinrich stadial 1 (17-15 ka), low enough to compensate for dry conditions in the region. Similar 
glacier advances coeval to Heinrich-1 have been documented in the mid latitudes of the northern hemisphere (e.g. Ivy-Ochs et al., 2006). In contrast, the fact that deglaciation in Costa Rica and in the northern tropical Andes was in progress during Heinrich stadial 1 , is probably an expression of the bipolar seesaw hypothesis postulated for Heinrich events, i.e. cooling in the Northern Hemisphere coeval to warming in the Southern Hemisphere (Handiani et al., 2012).

\section{Conclusions}

The LLGM in the mountains of Mexico (20-14 ka) and Central America ( 21-18 ka) falls within the final part of the global LGM (26.5-19 ka). Deglaciation started by $18 \mathrm{ka}$ in Costa Rica, shortly after the initial global glacier retreat identified by Clarke et al. (2009) at $19 \mathrm{ka}$. However, in Mexico glaciers remained near the maximum position until $\sim 15 \mathrm{ka}$, probably in connection with the cooling influence of Heinrich stadial 1.

Deglaciation commenced at 15-14 ka in central Mexico and got faster from 14 to $13 \mathrm{ka}$, in apparent coincidence with the Bølling-Allerød warming. A standstill or advance took place from 13 to $10.5 \mathrm{ka}$, thus spanning the Younger Dryas cool event. In Costa Rica, undated moraines also indicate stillstands sometime between 18 and $10 \mathrm{ka}$.

Full deglaciation across the region is recorded by $10 \mathrm{ka}$, except on the mountains of central Mexico >4,200 m.

During the LLGM (20-18 ka), the ELAS in central Mexico and Central America were depressed 1500-1000 m with respect to the modern regional ELA of $\sim 4900 \mathrm{~m}$ (Lachniet and Vázquez-Selem, 2005). This represents LLGM cooling of $9-6^{\circ} \mathrm{C}$ if the ELA was controlled only by temperature. Such data should serve as targets for general circulation models of LGM climate, and those models which do not produce ELAs or freezing lines around ca. $3500 \mathrm{~m}$ (or ca. $3900 \mathrm{~m}$ for more continental locations such as Iztaccíhuatl) should be investigated for explanations for the mismatch.

Overall, the deglacial record seems to be controlled by the march of temperature in central Mexico and Central America. An ELA rise of $300 \mathrm{~m}$ to $450 \mathrm{~m}$ (i.e. warming of $\sim 2-3^{\circ} \mathrm{C}$ ) with respect to the LLGM ELAs, could have produced full deglaciation on the mountains of Central America and those of central Mexico under $4200 \mathrm{~m}$.

While the early onset of deglaciation in Costa Rica (18 ka) is in line with the chronology of the northern tropical Andes, late deglaciation in central Mexico (15-13 ka) shows a pattern more characteristic of the western USA, including the possible influence of the Bølling-Allerød warming.

\section{Acknowledgements}

We thank two anonymous reviewers for constructive suggestions on how to improve this manuscript. The research was supported by UNAM-DGAPA-PAPIIT grants IN105213 and IN109216. 


\section{References}

Alley, R.B., Ágústsdóttir, A.M. 2005. The 8k event: cause and consequences of a major Holocene abrupt climate change. Quaternary Science Reviews 24 (10-11), 1123-1149. http://doi. org/10.1016/j.quascirev.2004.12.004.

Anderson, T.H. 1969. First evidence of glaciation in Sierra Los Cuchumatanes Range, northwestern Guatemala. Geological Society of America Special Paper 121, 387.

Anderson, T.H. 1969. Geology of the San Sebastian Huehuetenango quadrangle, Guatemala. Ph.D. dissertation, University of Texas, Austin.

Angel, I., Audemard, F.A., Carcaillet, J., Carrillo, E., Beck, C., Audin, L. 2016. Deglaciation chronology in the Mérida Andes from cosmogenic 10Be dating (Gavidia valley, Venezuela). Journal of South American Earth Sciences 71, 235-247. http://doi.org/10.1016/j. jsames.2016.08.001.

Arce, J.L., Macías, J.L., Vázquez-Selem, L. 2003. The 10.5 ka Plinian eruption of Nevado de Toluca volcano, Mexico: Stratigraphy and hazard implications. Geological Society of America Bulletin 115 (2), 230-248.

Barquero, J., Ellenberg, L. 1986. Geomorphologie der alpinen Stufe des Chirripo in Costa Rica. Geomorphology bar of the Alpine levels of the Chirripo in Costa Rica. Eiszeitalter und Gegenwart 36, 1-9.

Bergoeing, G. 1978. Modelado glaciar en la Cordillera de Talamanca, Costa Rica. Informe Semestral del Instituto Geográfico Nacional Julio-Diciembre 1977, 33-44.

Broecker, W.S., Denton, G.H., Edwards, R.L., Cheng, H., Alley, R.B., Putnam, A.E. 2010. Putting the Younger Dryas cold event into context. Quaternary Science Reviews 29 (9-10), 10781081. http://doi.org/10.1016/j.quascirev.2010.02.019.

Carrasco-Núñez, G., Siebert, L., Díaz-Castellón, R., Vázquez-Selem, L., Capra, L. 2010. Evolution and hazards of a long-quiescent compound shield-like volcano: Cofre de Perote, Eastern Trans-Mexican Volcanic Belt. Journal of Volcanology and Geothermal Research 197 (1-4), 209-224. http://doi.org/10.1016/j.jvolgeores.2009.08.010.

Castro-Govea, R., Siebe, C. 2007. Late Pleistocene-Holocene stratigraphy and radiocarbon dating of La Malinche volcano, Central Mexico. Journal of Volcanology and Geothermal Research 162 (1-2), 20-42. http://doi.org/10.1016/j.jvolgeores.2007.01.002.

Clark, P.U., Dyke, A.S., Shakun, J.D., Carlson, A.E., Clark, J., Wohlfarth, B., Mitrovica, J.X., Hostetler, S.W., McCabe, A.M. 2009. The Last Glacial Maximum. Science 325 (5941), 710 714. http://doi.org/10.1126/science.1172873.

Cunningham, M., Stark, C., Kaplan, M., Schaefer, J., Galewsky, J., Yoo, J. 2015. Linking glacial erosion and low-relief landscapes in tropical orogens. American Geophysical Union Fall Meeting, San Francisco, CA.

Delgado Granados, H., Vázquez Selem, L., Cortés Ramos, J., Julio Miranda, P., Ontiveros González, G., Soto Molina, V.H. 2015. La criósfera en México. In: B. Martínez López (Ed.), Reporte Mexicano de Cambio Climático. Grupo I Bases científicas. Modelos y modelación, Vol. 1.2.3., Universidad Nacional Autónoma de México/Programa de Investigación en Cambio Climático, Ciudad de México, pp. 79-111.

Ehlers, J., Gibbard, P.L., Hughes, P.D. (Eds.) 2011. Quaternary Glaciations - Extent and Chronology. A closer look. Elsevier, Amsterdam, 1108 pp.

Espinasa-Pereña, R., Martín-Del Pozzo,A.L. 2006. Morphostratigraphic evolution of Popocatépetl volcano, México. In: C. Siebe, J.L. Macías, G.J. Aguirre-Díaz (Eds.), Neogene-Quaternary continental margin volcanism: A perspective from Mexico. Geological Society of America Special Paper 402, Penrose Conference Series, Boulder, pp. 115-137.

Granger, D.E., Lifton, N.A., Willenbring, J.K. 2013. A cosmic trip: 25 years of cosmogenic nuclides in geology. Geological Society of America Bulletin 125 (9-10), 1379-1402. http:// doi.org/10.1130/b30774.1. 
Handiani, D., Paul, A., Dupont, L. 2012. Tropical climate and vegetation changes during Heinrich Event 1: a model-data comparison. Climate of the Past 8 (1), 37-57. http://doi. org/10.5194/cp-8-37-2012.

Hastenrath, S. 1973. On the Pleistocene glaciation of the Cordillera de Talamanca, Costa Rica. Zeitschrift für Gletscherkunde und Glazialgeologie 9, 105-121.

Hastenrath, S. 1974. Spuren pleistozäner Vereisung in den Altos Cuchumatanes, Guatemala. Eiszeitalter und Gegenwart 25, 25-34.

Hastenrath, S. 2009. Past glaciation in the tropics. Quaternary Science Reviews 28 (9-10), 790798. http://doi.org/10.1016/j.quascirev.2008.12.004.

Heine, K. 1975. Studien zur jünquartären Glazialmorphologie mexikanischer Vulkane. Mit einem Ausblick auf die Klimaentwicklung. Das Mexiko Projekt der Deutschen Forschungsgemeinschaft Vol. VII, Franz Steiner, Wiesbaden, 178 pp.

Heine, K. 1976. Blockgletscher- und Blockzungen Generationen am Nevado de Touca, Mexiko. Die Erde 107 (4), 330-352.

Heine, K. 1983. Mesoformen der Periglazialstufe der semihumiden Randtropen, dargestellt an Beispilen der Cordillera Neovolcánica, Méxiko. Abhandlungen der Akademie der Wissenschaften in Göttingen, Mathematisch-Physicalische Klasse, Series III 35, 403-424.

Heine, K. 1988. Late Quaternary glacial chronology of the Mexican volcanos. Die Geowissenschaften 6 (7), 197-205.

Heine, K. 1994. The late-glacial moraine sequences in Mexico: is there evidence for the Younger Dryas event? Palaeogeography, Palaeoclimatology, Palaeoecology 112, 113-123. http:// doi.org/10.1016/0031-0182(94)90136-8.

Horn, S.P. 1990. Timing of deglaciation in the Cordillera de Talamanca, Costa Rica. Climate Research 1, 81-83. http://www.jstor.org/stable/24863379.

Horn, S.P., Haberyan, K.A. 2016. Lakes of Costa Rica. In: M. Kappelle (Ed.), Costa Rican Ecosystems. University of Chicago Press, Chicago, pp. 656-682.

Ivy-Ochs, S., Kerschner, H., Kubik, P.W., Schlüchter, C. 2006. Glacier response in the European Alps to Heinrich Event 1 cooling: the Gschnitz stadial. Journal of Quaternary Science 21 (2), 115-130. http://doi.org/10.1002/jqs.955.

Jomelli, V., Favier, V., Vuille, M., Braucher, R., Martin, L., Blard, P.H., Colose, C., Brunstein, D., He, F., Khodri, M., Bourles, D.L., Leanni, L., Rinterknecht, V., Grancher, D., Francou, B., Ceballos, J.L., Fonseca, H., Liu, Z., Otto-Bliesner, B.L. 2014. A major advance of tropical Andean glaciers during the Antarctic cold reversal. Nature 513 (7517), 224-228. http://doi.org/10.1038/nature13546.

Kappelle, M., Horn, S.P. 2016. The Páramo Grasslands of Costa Rica’s Highlands. In: M. Kappelle (Ed.), Costa Rican Ecosystems. University of Chicago Press, Chicago, pp. 492523.

Lachniet, M.S., Asmerom, Y., Bernal, J.P., Polyak, V.J., Vazquez-Selem, L. 2013. Orbital pacing and ocean circulation-induced collapses of the Mesoamerican monsoon over the past 22,000 yr. Proceedings of the National Academy of Sciences 110 (23), 9255-9260. http:// doi.org/10.1073/pnas.1222804110.

Lachniet, M.S., Roy, A.J. 2011. Costa Rica and Guatemala. In: J. Ehlers, P.L. Gibbard, P.D. Hughes (Eds.), Quaternary Glaciations - Extent and Chronology. A closer look. Elsevier, Amsterdam, pp. 843-858. http://doi.org/10.1016/B978-0-444-53447-7.00060-X.

Lachniet, M.S., Seltzer, G.O. 2002. Late Quaternary glaciation of Costa Rica. Geological Society of America Bulletin 114 (5), 547-558.

Lachniet, M.S., Seltzer, G.O., Solís, L. 2005. Geología, geomorfología y depósitos glaciares en los páramos de Costa Rica. In: M. Kappele, S.P. Horn (Eds.), Páramos de Costa Rica. Instituto Nacional de Biodiversidad, INBio, Santo Domingo de Heredia, pp. 129-146. 
Lachniet, M.S., Vázquez-Selem, L. 2005. Last Glacial Maximum equilibrium line altitudes in the circum-Caribbean (Mexico, Guatemala, Costa Rica, Colombia, and Venezuela). Quaternary International 138-139, 129-144. http://doi.org/10.1016/j.quaint.2005.02.010.

Li, Y., Potter, R., Horn, S.P., Orvis, K.H. 2015. Late Quaternary Glacial Chronology in the Cordillera de Talamanca, Costa Rica, Investigated Using Cosmogenic Cl-36 Surface Exposure Dating, American Geophysical Union Fall Meeting, San Francisco, CA.

Lorenzo, J.L. 1961. Notas sobre la geología glacial del Nevado de Colima. Boletín del Instituto de Geología 61, 77-92.

Lowell, T.V. 2000. As climate changes, so do glaciers. Proceedings of the National Academy of Sciences 97 (4), 1351-1354. http://doi.org/10.1073/pnas.97.4.1351.

Lozano-García, S., Vázquez-Selem, L. 2005. A high elevation Holocene pollen record from Iztaccíhuatl volcano, central Mexico. The Holocene, 15 (3), 329-338. http://doi. org/10.1191/0959683605hl814rp.

Macías, J.L. 2005. Geología e historia eruptiva de algunos de los grandes volcanes activos de México. Boletín de la Sociedad Geológica Mexicana 67 (3), 379-424.

Marrero, S.M., Phillips, F.M., Caffee, M.W., Gosse, J.C. 2016. CRONUS-Earth cosmogenic 36Cl calibration. Quaternary Geochronology 31, 199-219. http://doi.org/10.1016/j. quageo.2015.10.002.

Nixon, G.T. 1989. The Geology of Iztaccíhuatl volcano and adjacent areas of the Sierra Nevada and Valley of Mexico. The Geological Society of America, Special Paper 219, Boulder, 58 pp.

Orvis, K.H., Horn, S.P. 2000. Quaternary Glaciers and Climate on Cerro Chirripó, Costa Rica. Quaternary Research 54 (1), 24-37. http://doi.org/10.1006/qres.2000.2142.

Ownby, S., Delgado Granados, H., Lange, R.A., Hall, C.M. 2007. Volcan Tancítaro, Michoacan, Mexico, 40Ar/39Ar constraints on its history of sector collapse. Journal of Volcanology and Geothermal Research 161 (1-2), 1-14. http://doi.org/10.1016/j.jvolgeores.2006.10.009.

Phillips, F.M., Zreda, M., Plummer, M.A., Elmore, D., Clark, D.H. 2009. Glacial geology and chronology of Bishop Creek and vicinity, eastern Sierra Nevada, California. Geological Society of America Bulletin 121 (7-8), 1013-1033. http://doi.org/10.1130/b26271.1.

Potter, R.S. 2015. Establishing a chronology of Late Quaternary Glacial advances in the Cordillera de Talamanca, Costa Rica. Master's thesis, University of Tennessee-Knoxville, $110 \mathrm{pp}$.

Rosen, J.L., Brook, E.J., Severinghaus, J.P., Blunier, T., Mitchell, L.E., Lee, J.E., Edwards, J.S., Gkinis, V. 2014. An ice core record of near-synchronous global climate changes at the Bolling transition. Nature Geoscience 7 (6), 459-463. http://doi.org/10.1038/ngeo2147.

Roy, A.J., Lachniet, M.S. 2010. Late Quaternary glaciation and equilibrium-line altitudes of the Mayan Ice Cap, Guatemala, Central America. Quaternary Research 74 (1), 1-7. http://doi. org/10.1016/j.yqres.2010.04.010.

Schimmelpfennig, I., Benedetti, L., Finkel, R., Pik, R., Blard, P.-H., Bourlès, D., Burnard, P., Williams, A. 2009. Sources of in-situ ${ }^{36} \mathrm{Cl}$ in basaltic rocks. Implications for calibration of production rates. Quaternary Geochronology 4 (6), 441-461. http://doi.org/10.1016/j. quageo.2009.06.003.

Schimmelpfennig, I., Benedetti, L., Garreta, V., Pik, R., Blard, P.-H., Burnard, P., Bourlès, D., Finkel, R., Ammon, K., Dunai, T. 2011. Calibration of cosmogenic ${ }^{36} \mathrm{Cl}$ production rates from $\mathrm{Ca}$ and $\mathrm{K}$ spallation in lava flows from Mt. Etna $\left(38^{\circ} \mathrm{N}\right.$, Italy) and Payun Matru $\left(36^{\circ} \mathrm{S}\right.$, Argentina). Geochimica et Cosmochimica Acta 75 (10), 2611-2632. http://doi.org/10.1016/j. gca.2011.02.013.

Schimmelpfennig, I., Schaefer, J.M., Putnam, A.E., Koffman, T., Benedetti, L., Ivy-Ochs, S., Team, A., Schlüchter, C. $2014 .{ }^{36} \mathrm{Cl}$ production rate from K-spallation in the European Alps (Chironico landslide, Switzerland). Journal of Quaternary Science, 29 (5), 407-413. http:// doi.org/10.1002/jqs.2720. 
Seltzer, G.O., Rodbell, D.T., Baker, P.A., Fritz, S.C., Tapia, P.M., Rowe, H.D., Dunbar, R.B. 2002. Early Warming of Tropical South America at the Last Glacial-Interglacial Transition. Science 296 (5573), 1685-1686. http://doi.org/10.1126/science.1070136.

Shimizu, C. 1992. Glacial landforms around Cerro Chirripo in Cordillera de Talamanka, Costa Rica. Chigaku Zasshi 101 (7), 615-621.

Sosa-Ceballos, G., Gardner, J.E., Siebe, C., Macías, J.L. 2012 . A caldera-forming eruption 14,100 ${ }^{14} \mathrm{C}$ yr BP at Popocatépetl volcano, México: Insights from eruption dynamics and magma mixing. Journal of Volcanology and Geothermal Research 213-214, 27-40. http://doi. org/10.1016/j.jvolgeores.2011.11.001.

Stansell, N.D., Abbott, M.B., Polissar, P.J., Wolfe, A.P., Bezada, M., Rull, V. 2005. Late Quaternary deglacial history of the Mérida Andes, Venezuela. Journal of Quaternary Science 20 (7-8), 801-812. http://doi.org/10.1002/jqs.973.

Vázquez-Selem, L. 1997. Late Quaternary glaciations of Téyotl volcano, central Mexico. Quaternary International, 43/44, 67-73. http://doi.org/10.1016/S1040-6182(97)00022-0.

Vázquez-Selem, L. 2000. Late Quaternary glacial chronology of Iztaccíhuatl volcano, central Mexico. A record of environmental change in the border of the tropics. Ph.D. Dissertation, Arizona State University, Tempe, $210 \mathrm{pp}$.

Vázquez-Selem, L., Heine, K. 2011. Late Quaternary Glaciation in Mexico. In: J. Ehlers, P.L. Gibbard, P.D. Hughes (Eds.), Quaternary Glaciations - Extent and Chronology. A closer look. Elsevier, Amsterdam, pp. 849-861. http://doi.org/10.1016/B978-0-444-53447-7.00061-1.

Weyl, R. 1956. Auf den Spuren eiszeitlicher Gletscher in der Cordillera de Talamanca. [Part] 5 of Geologische Wanderungen durch Costa Rica. Natur und Volk, 410-421.

Weyl, R. 1956. Eiszeitliche Gletscherspuren in Costa Rica (Mittelamerika). Zeitschrift für Gletscherkunde und Glazialgeologie 3, 317-325.

Weyl, R. 1956. Spuren eiszeitlicher Vergletscherung in der Cordillera de Talamanca Costa Ricas (Mittelamerika). Neues Jahrbuch für Geologie und Paläontologie - Abhandlungen 102, 283294.

White, S.E. 1962. Late Pleistocene glacial sequence for the West side of Iztaccíhuatl Volcano, México. Geological Society of America Bulletin 73 (8), 935-958.

White, S.E. 1981. Equilibrium line altitudes of Late Pleistocene and recent glaciers in Central Mexico. Geografiska Annaler 63A (3-4), 241-249. http://doi.org/10.2307/520837.

White, S.E. 1986. Late Pleistocene glacial stratigraphy and chronology of Mexico. Quaternary Science Reviews 5, 201-205. http://doi.org/10.1016/0277-3791(86)90186-1.

White, S.E., Valastro, S. 1984. Pleistocene Glaciation of Volcano Ajusco, Central Mexico, and comparison with the Standard Mexican Glacial Sequence. Quaternary Research 21 (1), 21 35. http://doi.org/10.1016/0033-5894(84)90086-3.

Young, N.E., Briner, J.P., Leonard, E.M., Licciardi, J.M., Lee, K. 2011. Assessing climatic and nonclimatic forcing of Pinedale glaciation and deglaciation in the western United States. Geology 39 (2), 171-174. http://doi.org/10.1130/G31527.1. 